\title{
COVID-19, el tsunami mundial
}

\section{COVID-19, The world's tsunami}

\author{
Francisco Moreno Sánchez*
}

Hasta diciembre de 2019 vivíamos con la sensación de que la salud era parte normal de nuestras vidas, la enfermedad ocurría sólo en personas vulnerables, de edad avanzada o descuidadas en sus hábitos. Las enfermedades consistían en gripas, intoxicaciones alimenticias o malestares psicosomáticos que se resolvían con un par de tabletas, una llamada médica o tres sesiones de terapia. El ser humano del siglo XXI se había olvidado de la posibilidad de una epidemia, eso sólo era tema de series de televisión o películas de ciencia ficción.

Es probablemente la incredulidad y la ignorancia lo que ha llevado al caos, sinónimo de esta pandemia por SARS-COVID-2 o mejor conocido como COVID-19.

Los primeros reportes que provenían de China eran tomados con morbo y sin la conciencia del problema que se avecinaba a nivel mundial. Se trataba de una infección nueva que ponía en riesgo a toda la humanidad, pero esto ya había ocurrido con anterioridad y siempre había la forma de controlar los contagios y por lo tanto, la diseminación de una enfermedad nueva. Las pandemias del pasado, peste negra, viruela y la influenza de 1918-19 se consideraban como episodios históricos de una humanidad que carecía de los conocimientos científicos y la tecnología que creíamos nos volvía invencibles en la actualidad.

* Director de la línea de Servicio de Medicina Interna. Encargado del programa COVID-19. Centro Médico ABC.

Recibido para publicación: 01/06/2020. Aceptado: 03/06/2020.

Correspondencia:

Francisco Moreno Sánchez

E-mail: pacomore@gmail.com
Un primer reporte de la facilidad en la transmisibilidad del virus, contagio entre personas asintomáticas o presintomáticas, prendió la alerta a los epidemiólogos. El espectro de la infección iba desde los asintomáticos hasta los que en una semana presentaban una inflamación pulmonar mortal. Los médicos nos encontramos sin respuestas, expuestos por primera vez a una entidad desconocida, sin tratamiento específico y cuando se hacía el reconocimiento de los síntomas para la identificación y el aislamiento a los probables casos, era ya muy tarde porque la persona había expuesto a otros individuos antes de sentirse enfermo. Así, en unas cuantas semanas empezaron a surgir casos en otros países asiáticos y no mucho después en Europa.

Las preguntas que surgían eran: ¿pero, con qué se cura?, ¿qué compro para protegerme?, ¿cuándo estará disponible la vacuna?, ¿cómo mejoro mis defensas? Todas ellas preguntas que buscaban lo que siempre se había tenido, un remedio rápido para toda calamidad. Pero, cómo era posible que no hubiera nada para contrarrestar a este virus, cómo era posible que los médicos no supieran.

La epidemia en Italia se vivió con horror, ya que mostró las carencias que no queríamos ver. La cantidad de enfermos que rebasaban al sistema de salud, la necesidad de camas hospitalarias que siempre resultaron insuficientes y las unidades de medicina crítica con el uso de ventilación mecánica se volvieron lugares donde se tuvo que llevar a cabo una selección eugenésica, en la que se privilegiaba por primera vez en muchos años a los más jóvenes, los más fuertes y los menos enfermos, en otras palabras, a los que tenían mejores posibilidades de sobrevivir para así realizar una práctica desgarradora mediante la cual sólo algunos podían ser atendidos y los demás eran enviados a su casa con medidas paliativas sabiendo que fallecerían irremediablemente. 
Pero aun con todos esos signos de alarma, el mundo y sus líderes permanecían incrédulos y desviaban la atención para acusar al pesimismo, a la conspiración e incluso a sus adversarios políticos de una realidad que requería de inteligencia, ciencia y sobre todo de estadistas que analizaran el problema en una forma integral y adelantarse para tomar las medidas necesarias para mitigar lo que se vislumbraba en el futuro.

Y fue así como Asia no pudo contener la epidemia, Europa la sufrió con estragos en su población y ésta llegó a América, a Estados Unidos, al país más poderoso del mundo, cuyo líder se encontraba más preocupado por su reelección, la economía de mercado y la supremacía racial. Ciudades como Nueva York y Los Ángeles, sitios emblemáticos por su poder adquisitivo, fueron afectadas sin misericordia ocasionando que en pocas semanas Estados Unidos fuera el país con más muertes por esta pandemia.

Una enfermedad que aísla al enfermo, le quita en muchos casos la oportunidad de despedirse de sus seres queridos y agobia a los familiares y amigos al encontrarse lejos del que los necesita. El paciente queda solo en un lugar donde sus visitas son de individuos cubiertos de máscaras, lentes y batas que ven con temor su rostro que muestra la urgencia de respirar. Al final es el aire el que falta, algo gratuito e inherente a la vida, es eso lo que va faltando y lo que genera la mayor de las angustias para el que lo sufre y para quienes lo vemos partir.

Con ese paso implacable llegó el virus a las áreas más pobres del planeta, América Latina y África, países donde las necesidades económicas impedían el poder confinar a la población, donde la desigualdad se observaba en los mismos sistemas de salud que ya eran insuficientes para atender las necesidades básicas y por lo tanto, no se encontraban a la altura de la magnitud del problema. Una vez más la falta de liderazgo en muchos sitios ocasionó que la infección se dispersara a pasos descomunales ocasionando muerte, desolación, desesperanza.

Actualmente, los países con más defunciones en el mundo son Estados Unidos, Reino Unido, Brasil, Italia, Francia, España y México. Seguimos combatiendo al enemigo invisible sin armas específicas, sin métodos de control epidemiológico y sin una medicina basada en evidencia en medio de líderes que reparten culpas basadas en intrigas e ignorancia. Hoy en día, sigue habiendo personalidades que no creen en la enfermedad, cuyos intereses propios superan al de los que fueron sus votantes.

Una vez más el mundo enfrenta una pandemia, una vez más se buscan culpables del desastre y perdemos el tiempo en discusiones, acusaciones y decisiones equivocadas. Una vez más la naturaleza desnuda al ser humano y lo expone como es, vulnerable y egoísta. 